\title{
Equilibrium between tri- and tetra-coordinate chalcogenuranes is critical for cysteine protease inhibition
}

\author{
Gabriela D da Silva*, Rodrigo L O R Cunha ${ }^{\dagger}$ Mauricio D Coutinho Neto $\ddagger$
}

October 27, 2020

\begin{abstract}
There have been significant advances in the biological use of hypervalent selenium and tellurium compounds as cysteine protease inhibitors over the recent past. However, the full understanding of their reaction mechanisms in aqueous medium and the mechanism of cysteine proteases inhibition is still elusive. Kinetic studies suggest an irreversible inhibition mechanism, which was explained by forming a covalent bond between the enzyme sulfhydryl group and the chalcogen atom at its hypervalent state $(+4)$. However, it is still unclear the active form of the inhibitor present in the aqueous biological media. To uncover this question, we performed a theoretical investigation using density functional theory (DFT). This study investigated chloride ligand exchange reactions by oxygen and sulfur nucleophiles on hypervalent selenium and tellurium compounds. All tetra- and tri-coordinate chalcogen compounds and distinct protonation states of the nucleophiles were considered, totaling 34 unique species, 7 nucleophiles and 155 free energies rections. We discovered that chloride is easily replaced by a nonprotonated nucleophile $\left(\mathrm{SH}^{-}\right.$or $\left.\mathrm{OH}^{-}\right)$in $\mathrm{R}_{2} \mathrm{SeCl}_{2}$. We also found that tri-coordinate species are more stable than their tetra-coordinate counterparts, with selenoxide $\left(\mathrm{R}_{2} \mathrm{SeO}\right)$ protonation being strongly exergonic in acid $\mathrm{pH}$. These results suggest that the protonated selenoxide $\left(\mathrm{R}_{2} \mathrm{SeOH}^{+}\right)$is the most probable active chemical species in biological media. The computed energetic profiles paint a possible picture for the selenurane activity, with successive exergonic steps leading to a covalent inhibition of thiol dependent enzymes, like cysteine proteases. A second less exergonic pathway has also been uncovered, with a direct reaction to chalcogenonium cation $\left(\mathrm{R}_{2} \mathrm{SeCl}^{+}\right)$ as the inhibition step. The trends observed for the telluranes were similar, albeit with more exergonic reactions and a stronger trend to form bonds with oxygen species then selenuranes.
\end{abstract}

*ABCSim - Laboratório de simulação e modelagem, Centro de Ciências Naturais e Humanas, Universidade Federal do ABC, Santo André-SP, Brazil.

${ }^{\dagger}$ Laboratório de Biologia Química, Centro de Ciências Naturais e Humanas, Universidade Federal do ABC, Santo André-SP, Brazil.

${ }^{\ddagger}$ ABCSim - Laboratório de simulação e modelagem, Centro de Ciências Naturais e Humanas, Universidade Federal do ABC, Santo André-SP, Brazil. 
Keywords:

Enzymes inhibitors, density functional theory, selenuranes and chalcogenuranes 


\section{INTRODUCTION}

The increasing interest in selenium and tellurium compounds can be explained by their ever-expanding range of biological applications. ${ }^{1-8}$ there is a plethora of well succeeded biological models where organoselenium and organotellurium compounds demonstrated promising activities, their potential as therapeutic agents have not yet been fully uncovered. ${ }^{9-11}$ Notwithstanding their most studied antioxidant activities, electrophilic selenium and tellurium species display interesting reactivities towards bionucleophiles. ${ }^{12,13}$ Among electrophilic organochalcogen species, the hypervalent derivatives ( +4 oxidation state) shows reactivities towards thiols which imply in inhibition of cysteine cathepsins, ${ }^{5,14,15}$ arginine phosphatases ${ }^{16}$ or tyrosine phosphatases. ${ }^{17-19}$

The overexpression and exacerbate activity of cysteine cathepsins are related to several pathologies like cancer, arthritis, atherosclerosis, osteoporosis, cardiovascular and parasitic diseases. ${ }^{14,20-22}$ In such conditions, the inhibition of these enzymes is desired and considered as therapeutical strategies. Thus, some electrophilic selenium and tellurium compounds

showed a very good therapeutical profile in in vivo models of epilepsy, ${ }^{23}$ leishmaniasis, ${ }^{24-26}$ cancer $^{27-29}$ and Clostridium difficile infection in mice. ${ }^{30}$

It is hypothesized that the inhibition of these thiol-dependent enzymes occurs through the formation of a chalcogen-sulfur bond, resulting from ligand exchange reactions with thiolates of reactive cysteine residues in enzyme active sites. ${ }^{5}$ As the compounds investigated have exchangeable ligands, it is reasonable to question to which extent those ligands remains attached to the chalcogen atom in the active form of the drug, particularly when biological media has nucleophilic species with pH-regulated reactivity. Hydrolysis reactions can impair the activities of these compounds or lead to more reactive species. Previous experimental studies demonstrated that chalcogenuranes readily react in water and organic solvents mixtures, showing that the inorganic chalcogenranes with chloride and alkoxy ligands decompose to hydrolyzed products. ${ }^{31-33}$

On the other hand, organic telluranes showed remarkable stability in the presence of water and phosphate buffer at $\mathrm{pH} 7.4$ and acid media with $\mathrm{pH}$ approximately 1 or 5.5 (in acetate buffer) when organic moieties are aryl and vinyl groups. ${ }^{31}$ It is important to note 
that these conversions retain the hypervalent state of the chalcogen atom and its bioactivity towards thiol nucleophiles.

The detailed understanding of the reaction pathways and relative stability of the several possible hypervalent species present in a multi-nucleophile aqueous media is relevant to the development of new inhibitor compounds with improved reactivities and stabilities. To gain insight into those pathways, we considered reactions involving simple nucleophiles: $\mathrm{Cl}^{-}$, $\mathrm{SH}^{-}$, and $\mathrm{OH}^{-}$with dichloro dimethylselenurane as a model. Thus, the study of ligand exchange reactions in these compounds is relevant to i) characterize the relative stability of several species of selenium(IV), and tellurium(IV) compounds that can be formed in aqueous solution and in-vivo; ii) understand the nature of the distinct reactive species formed and iii) propose a mechanism of action of chalcogenurane based drugs when inhibiting cysteine proteases.

In this work, we propose to investigate ligand exchange reactions involving simple nucleophiles and model selenurane compounds employing electronic structure methods. We have selected for start our investigation with $\mathrm{R}_{2} \mathrm{YCl}_{2}$ (as $\mathrm{Y}$ is selenium or tellurium) show in Figure 1. We chose these compounds because, from a computational point of view, these compounds $\left(\mathrm{Me}_{2} \mathrm{SeCl}_{2}\right)$ and $\left(\mathrm{Ph}_{2} \mathrm{SeCl}_{2}\right)$ are simpler to work with and should account for most of the energetic and reactive properties of more complex diorganoselenurane systems. We also investigate ligand exchange reactions (LER) for tellurium compounds to understand the effect of the chalcogen atom on the overall compound reactivity. Moreover, tellurium compounds have been increasing in popularity as potential drugs with much of the same broad range of applicability as their selenium counterparts. Additionally, a more realistic investigation with cysteine (Cys) acting as the nucleophile was also considered.

\section{The Systems}

We present our results for two limiting conditions: a high $\mathrm{pH}$ condition where the nucleophiles are charged and non-protonated, and a low pH condition where the nucleophiles are protonated. Therefore, starting from the dichloride compound, we initially consider LER investigations for two sets of nucleophiles, namely $\mathrm{H}_{2} \mathrm{O} / \mathrm{OH}^{-}$and $\mathrm{H}_{2} \mathrm{~S}_{\mathrm{SH}} \mathrm{SH}^{-}$at low/high $\mathrm{pH}$. All 
products from the reactions with nucleophiles were considered, totaling 10 compounds per $\mathrm{R}$ group to each chalcogen, Se and Te (named A to J in Fig. 1). Among them We also investigated single exchange reactions and the formation of tri-coordinate species, namely the oxide and cations. These were included due to their recent proposed relevance in selenurane ${ }^{34,35}$ and tellurane reactions. ${ }^{3,4}$ A total of 34 species and their 155 interconversion free energies were evaluated to paint a complete picture of LER on hypervalent selenium and tellurium compounds. Our goal is to assess the relevant equilibrium species for diorgano selenurane and tellurane compounds in a multi-nucleophile aqueous environment as the biological media. We report these equations considering the neutral/alkaline and acid conditions, the latter being particularly relevant to understand the equilibrium present in acidic cellular compartments like lysosomes. Moreover, with the exception the cathepsin S, cathepsins are optimally active and stable at slightly acidic $\mathrm{pH} .{ }^{36}$

\section{METHODOLOGY}

\section{Computational Details}

Density Functional Theory (DFT) ${ }^{37,38}$ using the B3LYP ${ }^{39}$ functional and 6-311-G+(d) ${ }^{40-42}$ basis set was used to obtain equilibrium geometries and energies for all selenurane derivatives (Fig. 1). Dispersion corrections were introduced employing the D3 functional correction from S. Grimme and collaborators. ${ }^{43,44}$ Frequency calculations were performed to ensure that a minimum was reached, to provide zero-point energy (ZPE) and free energy corrections (at $298.15 \mathrm{k}$ and $1 \mathrm{~atm})$.

All calculations were performed using the software Orca v3.0.3. ${ }^{45}$ For further reference, we named the selected methodology as DFT/B3LYP-D3/6-311G+(d). Solvent effects were introduced with the SMD model ${ }^{46}$ using the default settings as implemented in Orca v3.0.3 (which uses $\mathrm{COSMO}^{47}$ for the electrostatic part and non-polar components from TrhularCramer $\left.^{46}\right)$. For tellurium compounds, we used the $\mathrm{ECP}^{48}$ based LANL ${ }^{49}$ functional for Te and $6-311 \mathrm{G}+(\mathrm{d})$ for the other elements. To assess the quality of the DFT/B3LYP-D3/6- 
$311 \mathrm{G}+(\mathrm{d})$ results for we have compared it against the same method for selenium compounds using a large basis set (aug-cc-pvtz) $)^{50-52}$ and to higher-level electronic structure methods. More specifically, we choose for our assessment the B2PLYP ${ }^{53,54}$ and $\mathrm{LPNO}^{55}$ methods.

\section{Assessment With Higher Level Methods}

Performance of the B3LYP/6311-G+(d,p) methodology was compared experimental geometric data and to higher level methods, namely, the LPNO ${ }^{55}$ and the double hybrid B2PLYP 53,54 functional and to B3LYP using a larger aug-cc-pvtz basis set. Figure S1 (Supplemental information) shows the quantities compared (bonds and angles) and Table 1 brings the deviations to experimental x-ray data for the (dichloro- $\lambda 4$-selanediyl)dimethane $\left(\mathrm{Me}_{2} \mathrm{SeCl}_{2}\right)$ and dimethylselenoxide $\left(\mathrm{Me}_{2} \mathrm{SeO}\right)$, compounds $\mathrm{A}$ and $\mathrm{G}$ from figure $1, R_{1}=$ $R_{2}=M e$. Computed bond lengths for (a) $\mathrm{Se}-\mathrm{Cl}$ and (b) $\mathrm{Se}-\mathrm{O}$ were contrasted to reference experimental DRX data ${ }^{56,57}$ of 2.41 and 1.67 respectively while reference angle values for $(\alpha) \mathrm{Cl}-\mathrm{Se}-\mathrm{Cl}$ and $(\beta) \mathrm{C}-\mathrm{Se}-\mathrm{O}$ were 177.6 and 103.0 degrees respectively. Table 1 list the percentage error with respect to experimental values for bond length and angles. The overall agreement between the distinct electronic structure methods is excellent, with a mean average deviation of only $0.77 \%$.

\section{Ion Solvation Energies}

Most of the discussed equilibrium equations have small ions as reactants and products. We follow a procedure proposed by Pliego and Riveros ${ }^{58,59}$ to improve the computed solvation energies when compared to pure implicit solvent calculations. In this procedure, the solvation energy is computed for small water clusters, and a thermodynamic cycle is used to extract the solvation energy of the ionic species. ${ }^{60,61}$ Computed solvation energies using this procedure and the SMD method produced values very close to the accepted reference values for $\mathrm{H}_{3} \mathrm{O}^{+}$and $\mathrm{OH}^{-}$, being -108.11 and $-101.95 \mathrm{kcal}^{\mathrm{mol}}{ }^{-1}$ respectively. These values were much improved from standard SMD values using the single ionic species in the calculation. The computed solvation energy values for $\mathrm{Cl}^{-}$and $\mathrm{SH}^{-}$were -72.58 and $-69.60 \mathrm{kcal}^{\mathrm{mol}} \mathrm{mol}^{-1}$ 
respectively.

\section{RESULTS AND DISCUSSION}

\section{LER of tetra-coordinates species: chalcogenuranes}

Figure 2 shows the pathways for a total of 10 distinct ligand exchange reactions for diorgano selenuranes involving tetra-coordinate species while figure 3 shows interconversions involving the tri-coordinate species (chalcogenoxides and chalcogenonium cations). Labels are attributed ranging from 1 to 20 to reactions in neutral/alkaline conditions (considering the nucleophiles protonation at $\mathrm{pH}$ equal or bigger than 7), from 1' to 19' to reactions in acidic conditions (considering the nucleophiles protonation at $\mathrm{pH}$ smaller than 7 , representing the acidic organelles) and from 3" to 16" when cysteine acts as the nucleophile. Their respective free energies are presented in tables 2,3 and 4 .

Results for the double exchange reactions (4 and 10 from 2 forming $\mathrm{E}$ and $\mathrm{C}$ ) show that reactions with either sulfhydryl or hydroxyl are nearly isoexerrgonic at -37.7 and -37.1 kcal. $\mathrm{mol}^{-1}$, respectively. One can see that chloride is easily replaced by both nucleophiles $\left(\mathrm{OH}^{-}\right.$and $\left.\mathrm{SH}^{-}\right)$when nonprotonated species are considered, with the exchange of chloride by sulfhydryl leading to slightly more stable species, being -23.52 and $-14.15 \mathrm{kcal}_{\mathrm{mol}} \mathrm{m}^{-1}$ for first and second replacements (reactions 3 e 7 ). The difference between sulfhydryl and hydroxyl (both disubstituted, reaction 4 and 10), however, is only $0.6 \mathrm{kcal}_{\mathrm{mol}} \mathrm{mor}^{-1}$ for $\mathrm{R}=\mathrm{Me}$ and $5 \mathrm{kcal} . \mathrm{mol}^{-1}$ for $\mathrm{R}=\mathrm{Ph}$. Therefore, starting from the dichlorinated selenurane A, the disulfhydryl compound $\mathrm{E}$ with $\mathrm{R}=\mathrm{Ph}\left(\mathrm{Ph}_{2} \mathrm{Se}(\mathrm{SH})_{2}\right)$ has the most exergonic reaction path among tetra-coordinate selenurane species.

When protonated nucleophile are considered, the picture changed. Results for these strongly pH-dependent reactions are presented in table 3. The first for equations that were exergonic at alkaline/neutral conditions, now they were endergonic at acidic conditions. So, there is no favorable LER starting from the chloride bound species, indicating that for these reactions to occur, one needs nonprotonated nucleophiles. One noteworthy fact is that the exchange of hydroxyl by sulfhydryl groups is favorable for selenuranes as pointed out by 
reactions 5, 5', 6 (only for $R=P h$ ), 6', 8 and 8' in Tables 2 and 3 .

\section{LER of tri-coordinates species: selenoxide and selenonium cations}

The equilibrium between tri-coordinate species (compounds G, H. I and F), including the tri-coordinate interconversion reactions to produce tetra-coordinate species (compounds A, $\mathrm{C}, \mathrm{D}$ and $\mathrm{F}$ ), are shown in Fig. 3. The compound $\mathrm{C}$ can undergo dehydration (reaction 11 on table 2 ) leading to a very stable selenoxide species $(G)$. A similar path leads to an even more stable sulfhydryl species (I). However, it is known that this reactant can also undergo a disproportionation reaction ${ }^{62}$, resulting in a diorgano selenide compound ${ }^{63}$.

The obtained results point that, in aqueous solution at neutral or basic pH, the equilibrium should drive the formation of the dihydroxy species (compound $\mathrm{C}$ ) from $\mathrm{A}$, which is in equilibrium with selenoxide (compound $G$ ). In order to gain understanding into the key step of forming tri-coodinate species from four-coordinate ones, barrier estimates for reactions 11 and 12 that lead to selenoxide (compound $\mathrm{G}$ ) and its protonated form (compound $\mathrm{H}$ ) from dihydroxy compound $\mathrm{C}$ at alkali and acidic conditions were calculated. We added explicit water molecules, hydronium and hydroxide ions in the mechanism investigation that lead to tri-coodinate species $\mathrm{G} / \mathrm{H}$. The pictorial representation of this mechanisms are shown in the Figure 4 and the energy profile for the reactions are shown in figure S3. We found that there is no barrier for the dehydration reaction in acidic media (forming $\mathrm{H}$ ), while a barrier of 9 kcal.mol ${ }^{-1}$ was found for the alkaline media (forming G). Therefore, kinetic results suggest a quick dehydration of the dihydroxy compound $\mathrm{C}$ in acidic and a slow one in basic media. Our

findings are consistent with experimental results that point to an equilibrium between the methyl-substituted selenoxide (compound G) and its dihydroxyl form (compound C). ${ }^{62-64}$ Kobayashi et al. showed that the racemization barrier of diastereomeric diaryl selenoxides

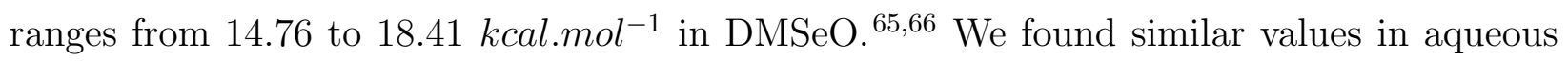
solution for the formation of a meta-stable dihydroxide species, reaction 11, with selenoxide

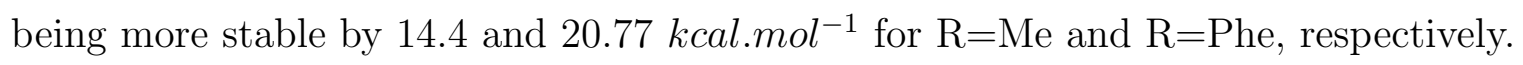


Moreover, selenoxide was also proposed as an intermediate generated from selenides under oxidative conditions in aqueous media. There, the selenoxide in its protonated form were proposed as intermediates in the formation of sulfhydryl-substituted selenuranes (compound F) ${ }^{63}$

Our results suggest that the equilibrium between such species is $\mathrm{pH}$-dependent (equation 13 and 13'), strongly favoring a protonated form $\left(\mathrm{DMSeOH}^{+}\right.$in acidic conditions, shown in Table 3). This species is susceptible to addition and exchange reactions from thiolates, as shown by reactions 14 and 15 and 15'. Therefore, the formation of sulfhydryl-substituted selenuranes is energetically allowed if nucleophiles are available. The effect of the organic ligand is monotonic, with $\mathrm{R}=\mathrm{Ph}$ favoring $-\mathrm{SH}$ bound compounds across the board by a few kilocalories (see reactions 17, 18, 19, and 20).

An acidic medium, however, hinders the formation of the dihydroxide species as the elimination of chloride requires an attack by a nonprotonated nucleophile (reactions 1 to 4 vs. 1' to 4').

A possible alternative mechanism for direct generation of tri-coordinate species from compound A could start from a slightly unfavorable $\mathrm{Cl}^{-}$elimination (reactions 17) followed by direct ligand exchange reactions between tri-coordinate species (reactions 18, 19, and 18', 19'). This mechanism is consistent with experimental results from Silva and Andrade. ${ }^{33}$ He showed that dichlorides and dibromides of 1-butylselenium- and 1-butyltellurium-2methoxymethyl-benzene exhibit a distinct behavior when in the presence of water. The halo-organoselenuranes lose one halide ligand leading to a tri-coordinate selenium(IV) species and the halo-organotelluranes hydrolyzed to the corresponding telluroxides but both selenium and tellurium species formed adducts with cysteine.

Therefore our results point to the formation of tri-coordinate species as the most stable

ones in solution in either basic or acid pH. Among the tri-coordinate species, the sulfur bound form is the most stable, and the chloride bound form is the least.

\section{Relevant species to cysteine proteases inhibition}

The exchange reaction energy profiles paint a possible picture for the protease inhibition 
mechanisms by selenuranes and telluranes. Based on our results, we propose that chloride is replaced by $\mathrm{OH}^{-}$in aqueous media at a neutral or slightly basic $\mathrm{pH}$ (use structures A/F) generating a dihydroxyl form $\left(\mathrm{DMSe}(\mathrm{OH})_{2}\right)$ that eliminates water and generates the selenoxide (DMSeO) species.

Direct addition of thiolate to $\mathrm{Me}_{2} \mathrm{SeO}$ is not energetically favorable. Therefore, enzymatic inhibition should happen in an acidic environment such as the one present in lysosomes, where selenoxide is protonated (species $\mathrm{H}$ ) and addition or ligand exchange by thiol group can take place. Moreover, it is well known from the literature ${ }^{56,57,67,68}$ that cysteine proteases create a micro-environment where the catalytic triad keeps the sulfhydryl group nonprotonated. We propose that cysteine $\left(\mathrm{Cys}^{-}\right)$reacts with $\mathrm{Me}_{2} \mathrm{SeOH}^{+}$generating a tetracoordinate species (compound F) followed by water elimination in acid conditions (reaction 16"). More specifically, a direct addition of cysteine's thiolate to $\mathrm{Me}_{2} \mathrm{SeOH}^{+}$can occur in a $\mathrm{pH}$ window where $\mathrm{Me}_{2} \mathrm{SeOH}^{+}$and $\mathrm{Cys}^{-}$coexist (that is a $\mathrm{pH}$ window where $p K_{a}\left(\mathrm{R}_{2} \mathrm{SeOH}^{+}\right.$) $\left.>\mathrm{pH}>p K_{a}(\mathrm{Cys})\right)$. The overall ligand exchange free energy is given by equation 15". The steps of this inhibition pathway are depicted in the figure 5 and is named mechanism 1. Therefore, if the stable tri-coordinate selenoxide species is formed, an acidic environment, either explicit or trough a micro enzyme environment, is necessary for the formation of sulfur-selenium bonds that characterizes a covalent inhibition (generating compounds $\mathrm{F}$ or I like).

In acidic $\mathrm{pH}$ (only considering protonated species), the previously described pathway is inhibited. However, protonated selenoxide $(\mathrm{H})$ can be formed by direct elimination of $\mathrm{Cl}^{-}$ from A (reaction 17 forming $\mathrm{J}$ ), followed by a ligand exchange reaction of the tri-coordinate species (reaction 18'). Both tri-coordinate species $\mathrm{H}$ and $\mathrm{J}\left(\mathrm{R}_{2} \mathrm{SeOH}^{+}\right.$and $\left.\mathrm{R}_{2} \mathrm{SeCl}^{+}\right)$can react with a thiolate generating the sulfur bound species F and I trough reactions 19 and 21. Figure 5 bottom panel shows this second proposed inhibition pathway, including species $\mathrm{DMeYCl}^{+}$- mechanism 2. This second proposed inhibition pathway is named mechanism 2 and is consistent with findings from Silva and Andrade. ${ }^{33}$ It is interesting to note that these tri-coordinate species (compound $\mathrm{H}$ and $\mathrm{J}$ ) can also react spontaneously with a protonated thiol as shown by reactions 15' and 19'. 


\section{Cysteine as a nucleophile with physiological implications}

To better model the energetic of the enzymatic inhibition reaction, we investigate LER using cysteine as a nucleophile (Table 4. For this investigation, we only considered the dimethyl $\mathrm{Me}_{2} \mathrm{SeCl}_{2}$ as the starting reagent. Note that free cysteine is protonated in physiological $\mathrm{pH}$ with its $\mathrm{pKa}$ of 8.3. However, we used $\mathrm{Cys}^{-}$because its is the form in the catalitic dyad of the enzyme. Results obtained are similar to the ones obtained using sulfhydryl $\left(\mathrm{SH}^{-}\right)$as nucleophiles. As noted for $\mathrm{H}_{2} \mathrm{~S} / \mathrm{SH}^{-}$, the cysteine sulfhydryl group is capable of displacing $\mathrm{OH}$ group in both the tetra-coordinate and tri-coordinate species (reactions 5", 6", 8" and 15"). Moreover, exchange reactions for the tri-coordinate species become more exergonic, favoring the formation of a Sulfur-selenium bond. Therefore, in a multi nucleophile environment, the sulfur bound species will dominate once chloride is displaced. This results are expected as Cys is a stronger nucleophile then $\mathrm{H}_{2} \mathrm{~S}$. In our calculations, we considered the neutral non-zwitterionic form of cysteine as it models more precisely the chemical environment as part of a polypeptide chain. This is consistent with results from Nascimento et $a .^{63}$

\section{Ligand exchange reactions starting from diorgano tellurium dichlorides}

We also investigate ligand exchange reactions investigations were Te replaces Se in all structures with $\mathrm{R}=\mathrm{Me}$ to explore the chalcogen effect on reactivity (Table S1 - Supplementary information). Similar reaction trends have been observed for diorgano telluranes when compared to diorgano selenuranes. For example, the exchange of chloride by hydroxyl in

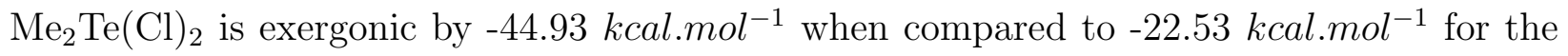
Se analog. Nonetheless, there are a few critical differences in reactive behavior that are worth mentioning.

The formation of tri-coordinate chloride species by direct $\mathrm{Cl}^{-}$elimination is strongly favorable, $\mathrm{Te}=-36.9$ and $\mathrm{Se}=1.5 \mathrm{kcal}_{\mathrm{mol}} \mathrm{mol}^{-1}$ (reaction 17 from table S1). Further exchange of chloride by $\mathrm{OH}^{-}$or $\mathrm{SH}^{-}$is exergonic and, unlike its selenium counterpart, happens re- 
gardless of the protonation state of the nucleophile (reactions 18,19, and 18', 19' from table $\mathrm{S} 1)$. Therefore, the formation mechanism for oxygen and sulfur bound tri-coordinate species directly from $\mathrm{J}$ seems to be preferred for tellurane compounds regardless of $\mathrm{pH}$.

Ligand exchange of the tetra-coordinate species A is allowed thermodynamically regardless of pH (for example, reactions 1 to 4 and 1' to 4' from table S1). Still, these species are higher in energy when compared to their tri-coordinate counterparts. In any case, we found that telluroxide $\mathrm{Me}_{2} \mathrm{TeO}$ is the more stable form in solution in agreement with experimental results. ${ }^{65,69,70}$.

We also found that telluranes are also more selective when compared to selenuranes, with a marked preference towards forming Te-O bonds. The ligand exchange reaction of hydroxyl by sulfhydryl group on telluranes is strongly endothermic in comparison with selenium compounds at neutral/alkaline conditions. For example, it is necessary $42.46 \mathrm{kcal}_{\text {.mol }}^{-1}$ to generate the $\mathrm{Me}_{2} \mathrm{Te}(\mathrm{SH})_{2}$ from $\mathrm{Me}_{2} \mathrm{Te}(\mathrm{OH})_{2}$. These differences can be clearly noted in table S1 from the supplemental material.

Telluranes exhibit a stronger affinity towards oxygen, and telluroxide has a more pronounced relative stability. Therefore, for inhibition to occur through the same mechanisms as previously proposed and shown in 5, a stronger nucleophile species on the enzyme is needed when compared to sellenuranes.

\section{CONCLUSIONS}

Chalcogenuranes are promising as cysteine proteases inhibitors and form an important class of compounds against several maladies. Covalent inhibition of these thiol-dependent enzymes occurs through the formation of a chalcogen-sulfur bond. However, there is still lack a detailed understanding of the reaction pathways in a multi-nucleophile environment and on the nature of the active form of organochalcogenuranes.

In this work, we performed a thorough investigation of ligand exchange reactions involving simple nucleophiles $\left(\mathrm{SH}^{-}, \mathrm{OH}^{-}, \mathrm{Cl}^{-}\right.$, Cysteine) and model diorgano chalcogenurane

compounds (alkyl and aryl derivatives) using Density functional Theory and SMD to account for solvent effects. Our investigation aimed at characterizing the relative stability of several 
species of selenium(IV) and tellurium(IV) compounds to gain insight into the mechanism of action of chalcogenurane based drugs when inhibiting cysteine proteases. We assessed the quality of our results towards higher-level electronic structure methods and experimental solvation energies.

Our results point towards two limiting mechanisms depending on $\mathrm{pH}$ and nucleophile availability. In mechanism 1, there is a spontaneous exchange of chloride groups leading to the formation of selenoxide, $\mathrm{R}_{2} \mathrm{SeO}$ (Figure 5, up panel). In this pathway, $\mathrm{R}_{2} \mathrm{SeO}$ can be exothermically generated and then protonated at a $\mathrm{pH}<7$ and is likely to act as the active species towards inhibiting cysteine peptidases. A similar mechanism has been shown for selenides, which reacts with thiols after being oxidized in a GPx-like catalytic cycle ${ }^{63}$. Nonetheless, an alternate mechanism involving the formation of protonated selenoxide is allowed trough $\mathrm{Cl}^{-}$elimination and ligand exchange reactions. Then, inhibition can happen either through reaction with protonated selenoxide of direct reaction with the reactive tricoordinate species $\mathrm{R}_{2} \mathrm{SeCl}$ (Figure 5, down panel). In both reaction pathways, tri-coordinate species have essential roles in the inhibition mechanism.

Telluranes exhibit a very similar reaction profile to selenunares with one crucial difference. Our calculations suggest a strong preference for organotelluranes in forming tellurium-oxygen bonds when compared to selenunares. Therefore, as telluroxide is in solution, a stronger nucleophile is needed to displace $\mathrm{OH}^{-}$; moreover, the formation of tri-coordinate chloride species by direct $\mathrm{Cl}^{-}$elimination is energetically favorable for telluranes (Figure 5, compound J, bottom panel). Therefore, the mechanism of formation for oxygen and sulfur bound tricoordinate species directly from compound $\mathrm{J}$ may be preferred for tellurane compounds regardless of $\mathrm{pH}$. These results may explain the general higher activity of telluranes over selenuranes in experimental inhibition investigations.

The free energies reported herein are only valid for limiting conditions where the nucleophiles are presented in stoichiometric conditions. One should be aware that the in vivo reaction media typically offers very distinct quantities of nucleophiles, with $\mathrm{pH}$ ranging from 5 to 7 , and the amount of free sulfhydryl species strongly depends both on $\mathrm{pH}$ and on the oxidative state of the cell.$^{71,72}$ We hope the results comprised herein cast light on the complex chemistry displayed by organochalcogenuranes in aqueous biological media. Especially their 
interaction with nucleophilic thiols and, ultimately, with thiol-dependent proteins whose activities strongly relate with many physiopathologic conditions.

\section{ACKNOWLEDGMENTS}

The authors thanks the Coordenação de Aperfeiçoamento de Pessoal de Nível Superior (CAPES) Finance Code 001, Universidade Federal do ABC (UFABC) and CENAPAD-SP for the computational resources.

\section{CONFLICTS OF INTEREST}

The authors declare that there is no conflict of interest regarding the publication of this article. 


\section{References}

1. K. El-Bayoumy and R. Sinha, Mutation research 591, 224 (2006).

2. C. W. Nogueira and J. B. T. Rocha, Archives of Toxicology 85, 1313 (2011), ISSN $1432-0738$.

3. C. W. Nogueira, G. Zeni, and J. B. T. Rocha, Chemical Reviews 104, 6255 (2004).

4. L. A. Ba, M. Döring, V. Jamier, and C. Jacob, Org. Biomol. Chem. 8, 4203 (2010).

5. A. Albeck, H. Weitman, B. Sredni, and M. Albeck, Inorganic Chemistry 37, 1704 (1998), ISSN 0020-1669, URL http://pubs . acs .org. ezp-prod1 . hul . harvard . edu/doi/abs/10.1021/ic971456t.

6. J. V. Comasseto, Journal of the Brazilian Chemical Society 21, 2027 (2010), ISSN 01035053.

7. R. L. O. R. Cunha, I. E. Gouvea, and L. Juliano, Anais da Academia Brasileira de Ciências 81, 393 (2009), ISSN 0001-3765.

8. L. Wessjohann and A. Schneider, Chemistry \& Biodiversity 5, 375 (2008), https://onlinelibrary.wiley.com/doi/pdf/10.1002/cbdv.200890038, URL https://onlinelibrary.wiley.com/doi/abs/10.1002/cbdv. 200890038.

9. L. Orian and S. Toppo, Free Radical Biology and Medicine 66, 65 (2014), ISSN 08915849 , antioxidants.

10. H.-L. Seng and E. R. T. Tiekink, Applied Organometallic Chemistry 26, 655 (2012).

11. E. R. T. Tiekink, Dalton Trans. 41, 6390 (2012).

12. C. A. Bayse and K. N. Ortwine, European Journal of Inorganic Chemistry 2013, 3680 (2013).

13. C. A. Bayse and J. L. Brumaghim, eds., Modeling of Mechanisms of Selenium Bioactivity Using Density Functional Theory (Oxford University Press, Washington, DC, 2013), ISBN 978-0-8412-2903-7. 
14. L. Piovan, M. F. M. Alves, L. Juliano, D. Brömme, R. L. O. R. Cunha, and L. H. Andrade, Bioorganic and medicinal chemistry 19, 2009 -2014 (2011), ISSN 0968-0896.

15. L. Piovan, M. F. M. Alves, L. Juliano, D. Brömme, R. L. O. R. Cunha, and L. H. Andrade, Journal of the Brazilian Chemical Society 21, 2108 (2010), ISSN 0103-5053.

16. J. Fuhrmann, V. Subramanian, and P. R. Thompson, ACS Chemical Biology 8, 2024 (2013).

17. L. Piovan, L. Wu, Z.-Y. Zhang, and L. H. Andrade, Org. Biomol. Chem. 9, 1347 (2011).

18. M. Abdo, S. Liu, B. Zhou, C. D. Walls, L. Wu, S. Knapp, and Z.-Y. Zhang, Journal of the American Chemical Society 130, 13196 (2008).

19. C. C. Tjin, K. D. Otley, T. D. Baguley, P. Kurup, J. Xu, A. C. Nairn, P. J. Lombroso, and J. A. Ellman, ACS Central Science 3, 1322 (2017).

20. M. Fonović and B. Turk, PROTEOMICS - Clinical Applications 8, 416 (2014), ISSN 18628346.

21. J. H. McKerrow, E. Sun, P. J. Rosenthal, and J. Bouvier, Annual Review of Microbiology 47, 821 (1993), ISSN 0066-4227.

22. M. P. Rayman, The Proceedings of the Nutrition Society 64, 527 (2005), ISSN 00296651.

23. D. S. Persike, R. L. O. R. Cunha, L. Juliano, I. R. Silva, F. E. Rosim, T. Vignoli, F. Dona, E. A. Cavalheiro, and M. J. da Silva Fernandes, Neurobiology of disease 31, 120 (2008).

24. C. B. C. Lima, W. W. Arrais-Silva, R. L. O. R. Cunha, and S. Giorgio, Korean J Parasitol 47, $213(2009)$.

25. P. Vishwakarma, N. Parmar, P. Chandrakar, T. Sharma, M. Kathuria, P. K. Agnihotri, M. I. Siddiqi, K. Mitra, and S. Kar, Cellular and Molecular Life Sciences 75, 563 (2018), ISSN 1420-9071. 
26. I. A. S. Pimentel, C. d. S. Paladi, S. Katz, W. A. d. S. Júdice, R. L. O. R. Cunha, and C. L. Barbiéri, PLOS ONE 7, 1 (2012).

27. A. Silberman, Y. Kalechman, S. Hirsch, Z. Erlich, B. Sredni, and A. Albeck, ChemBioChem 17, 918 (2016).

28. T. Lin, Y. Chen, Z. Ding, G. Luo, J. Liu, and J. Shen, PLOS ONE 8, 1 (2013).

29. R. Coriat, W. Marut, M. Leconte, L. Ba, A. Vienne, C. Chereau, J. Alexandre, B. Weill, M. Doering, C. Jacob, et al., Cell death \& disease 2, e191 (2011).

30. K. O. Bender, M. Garland, J. A. Ferreyra, A. J. Hryckowian, M. A. Child, A. W. Puri, D. E. Solow-Cordero, S. K. Higginbottom, E. Segal, N. Banaei, et al., Science Translational Medicine 7, 306ra148 (2015), ISSN 1946-6234.

31. C. R. Princival, M. V. L. R. Archilha, A. A. Dos Santos, M. P. Franco, A. A. C. Braga, A. F. Rodrigues-Oliveira, T. C. Correra, R. L. O. R. Cunha, and J. V. Comasseto, ACS Omega 2, 4431 (2017).

32. K. D’Arcy, A. Doyle, K. Kavanagh, L. Ronconi, B. Fresch, and D. Montagner, Journal of inorganic biochemistry 198, 110719 (2019).

33. M. S. Silva and L. H. Andrade, Org. Biomol. Chem. 13, 5924 (2015).

34. V. P. Singh, H. B. Singh, and R. J. Butcher, European Journal of Inorganic Chemistry pp. 637-647 (2010), ISSN 14341948.

35. K. Selvakumar, H. B. Singh, N. Goel, U. P. Singh, and R. J. Butcher, Chemistry - A European Journal 18, 1444 (2012), https://onlinelibrary.wiley.com/doi/pdf/10.1002/chem.201003725, URL https://onlinelibrary.wiley.com/doi/abs/10.1002/chem. 201003725.

36. M. Fonović and B. Turk, Biochimica et Biophysica Acta (BBA) - General Subjects 1840, 2560 (2014), ISSN 03044165.

37. W. Kohn and L. J. Sham, Physical review 385, 1133 (1965). 
38. P. Hohenberg and W. Kohn, Physical review 155, 864 (1964).

39. C. Lee, W. Yang, and R. G. Parr, Physical Review B 37, 785 (1988).

40. A. D. McLean and G. S. Chandler, The Journal of Chemical Physics 72, 5639 (1980).

41. L. A. Curtiss, M. P. McGrath, J. Blaudeau, N. E. Davis, R. C. Binning, and L. Radom, The Journal of Chemical Physics 103, 6104 (1995).

42. R. Krishnan, J. S. Binkley, R. Seeger, and J. A. Pople, The Journal of Chemical Physics 72, $650(1980)$.

43. S. Grimme, S. Ehrlich, and L. Goerigk, journl of computational chemistry pp. 1456-1465 (2011).

44. S. Grimme, J. Antony, S. Ehrlich, and H. Krieg, The Journal of Chemical Physics 132, 154104 (2010), URL https://doi.org/10.1063/1.3382344.

45. F. Neese, Wiley Interdisciplinary Reviews: Computational Molecular Science 2, 73 (2012), ISSN 17590876, URL http://doi.wiley.com/10.1002/wcms.81.

46. A. V. Marenich, C. J. Cramer, and D. G. Truhlar, The Journal of Physical Chemistry B 113, 6378 (2009), ISSN 1520-6106, URL http://pubs.acs.org/doi/abs/10.1021/jp810292n.

47. A. Klamt and G. Schuurmann, journal chemical society pp. 799-805 (1993).

48. P. J. Hay and W. R. Wadt, The Journal of Chemical Physics 82, 299 (1985).

49. R. Flores-Moreno, R. J. Alvarez-Mendez, A. Vela, and A. M. Köster, Journal of Computational Chemistry 27, 1009 (2006), https://onlinelibrary.wiley.com/doi/pdf/10.1002/jcc.20410, URL https://onlinelibrary.wiley.com/doi/abs/10.1002/jcc. 20410.

50. T. H. Dunning, The Journal of Chemical Physics 90, 1007 (1989), URL https://doi.org/10.1063/1.456153. 
51. D. E. Woon and T. H. Dunning, The Journal of Chemical Physics 98, 1358 (1993), URL https://doi.org/10.1063/1.464303.

52. R. a. Kendall, T. H. Dunning Jr., and R. J. Harrison, J. Chem. Phys. 96, 6796 (1992), ISSN 1089-7690.

53. S. Grimme, The Journal of chemical physics 124, 034108 (2006).

54. S. Grimme and F. Neese, The Journal of chemical physics 127, 154116 (2007).

55. F. Pavošević, F. Neese, and E. F. Valeev, The Journal of chemical physics 141, 054106 (2014).

56. S. M. Godfrey, C. A. McAuliffe, R. Pritchard, and S. Sarwar, Journal of The Chemical Society-dalton Transactions - J CHEM SOC DALTON TRANS pp. 1031-1036 (1997).

57. A. S. Filatov, E. Block, and M. A. Petrukhina, Acta Crystallographica Section C: Crystal Structure Communications 61, 596 (2005), ISSN 01082701.

58. J. R. Pliego and J. M. Riveros, The Journal of Physical Chemistry A 105, 7241 (2001), ISSN 1089-5639, URL http://pubs.acs.org/doi/abs/10.1021/jp004192w.

59. J. R. Pliego Jr and J. M. Riveros, Phys. Chem. Chem. Phys. 4, 1622 (2002).

60. C. P. Kelly, C. J. Cramer, and D. G. Truhlar, Journal of Physical Chemistry B 110, 16066 (2006), ISSN 15206106, jp063552y.

61. E. F. Martins and J. R. Pliego, Journal of Molecular Catalysis A: Chemical 417, 192 (2016), ISSN 1381-1169, URL http://www.sciencedirect.com/science/article/pii/S1381116916300760.

62. M. R. Detty, A. E. Friedman, and A. R. Oseroff, Journal of Organic Chemistry 59, 8245 (1994), ISSN 15206904.

63. V. Nascimento, E. E. Alberto, D. W. Tondo, D. Dambrowski, M. R. Detty, F. Nome, and A. L. Braga, Journal of the American Chemical Society 134, 138 (2012), ISSN 00027863. 
64. Y. You, K. Ahsan, and M. R. Detty, Journal of the American Chemical Society 125, 4918 (2003), ISSN 00027863.

65. T. Shimizu, M. Yoshida, and M. Kobayashi, Bulletin of The Chemical Society of Japan - BULL CHEM SOC JPN 60, 1555 (1987).

66. L. Engman, D. Stern, M. Pelcman, and C. M. Andersson, Journal of Organic Chemistry 59, 1973 (1994), ISSN 15206904.

67. S. Hussain, A. Khan, S. Gul, M. Resmini, C. S. Verma, E. W. Thomas, and K. Brocklehurst, Biochemistry 50, 10732 (2011), ISSN 00062960.

68. A. Paasche, A. Zipper, S. Schäfer, J. Ziebuhr, T. Schirmeister, and B. Engels, Biochemistry 53, $5930 \quad$ (2014), ISSN 0006-2960, URL http: //pubs.acs.org/doi/abs/10.1021/bi400604t.

69. F. A. Davis, O. D. Stringer, and J. P. McCauley, Tetrahedron 41, $4747 \quad$ (1985), ISSN 0040-4020, URL http://www.sciencedirect.com/science/article/pii/S0040402001967134.

70. M. L. Teixeira, L. R. Menezes, A. Barison, A. R. de Oliveira, and L. Piovan, The Journal of organic chemistry $\mathbf{8 3 ,} 7341$ (2018).

71. E. S. G. Barron, Thiol Groups of Biological Importance (John Wiley \& Sons, Ltd, 2006), pp. 201-266, ISBN 9780470122563, URL https://onlinelibrary.wiley.com/doi/abs/10.1002/9780470122563.ch4.

72. L. B. Poole, Free Radical Biology and Medicine 80, 148 (2015), ISSN 18734596 , 15334406, URL http://dx.doi.org/10.1016/j.freeradbiomed.2014.11.013. 


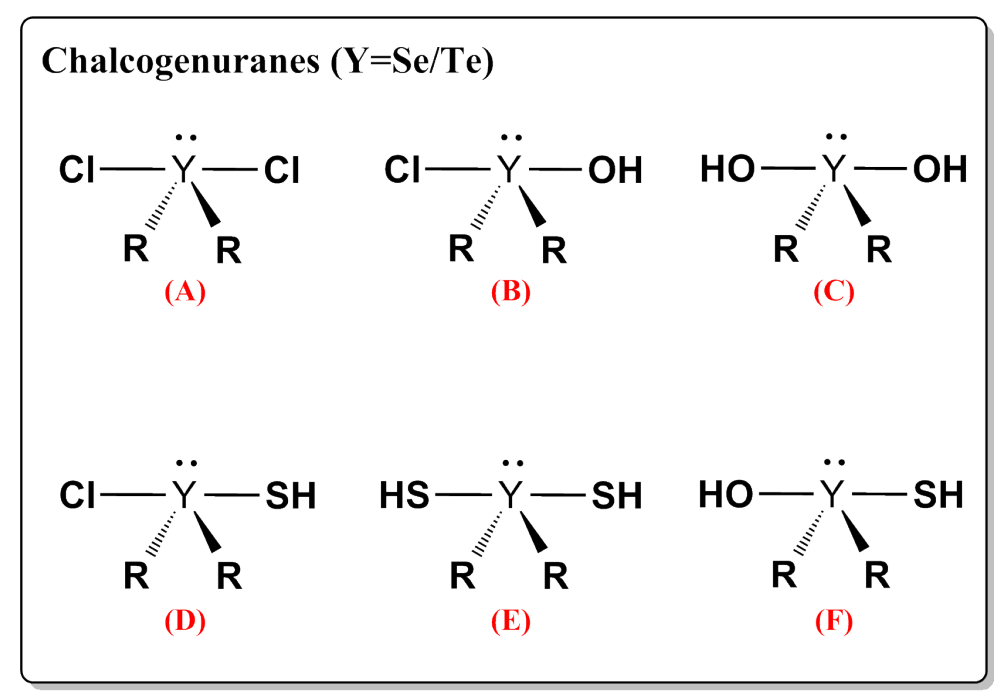

Chalcogenoxide

Chalcogenonium cations $(\mathrm{Y}=\mathrm{Se} / \mathrm{Te})$

$\mathbf{R}_{\mathbf{R}}^{\oplus} \ddot{\mathrm{Y}}_{\ddot{\prime \prime \prime \prime} \mathrm{OH}}$

(H)<smiles>[R][Y]([R])([R])O</smiles>

(G)<smiles>[R][Al]([R])Cl</smiles>

(J)<smiles>[R][Y19]([R])([R])[H]</smiles>

(I)

Figure 1: Structural chemistry of system under investigation molecules, where $R_{1}$ and $R_{2}$ are methyl and phenyl group, and $\mathrm{Y}$ is selenium or tellurium.

\section{$0.1 \quad$ Figures}




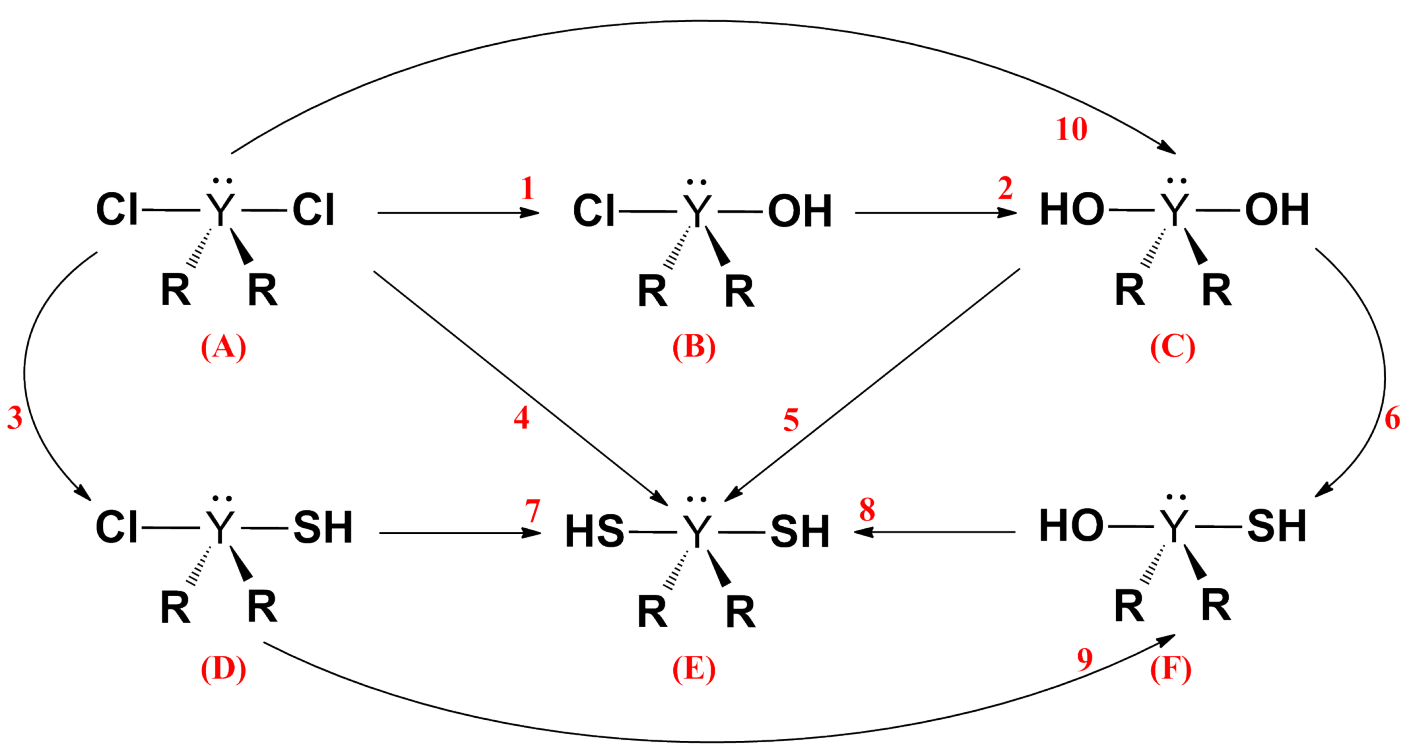

Figure 2: Pathways for ligand exchange reactions for tetra-coordinate selenuranes. The continuous arrow indicates the reaction direction as reported in Tables 1 and 2 . 


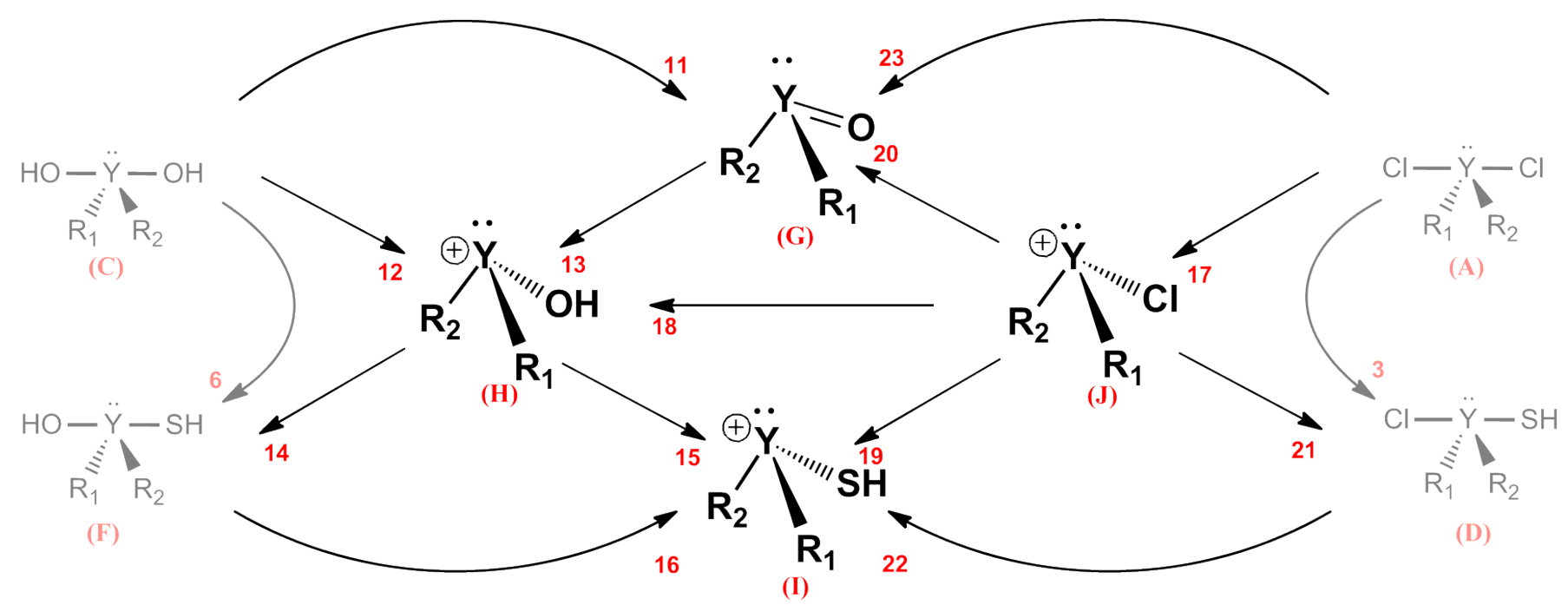

Figure 3: Pathways for ligand exchange reactions for tri-coordinate selenuranes. The continuous arrow indicates the reaction direction as reported in Tables 1 and 2 . 

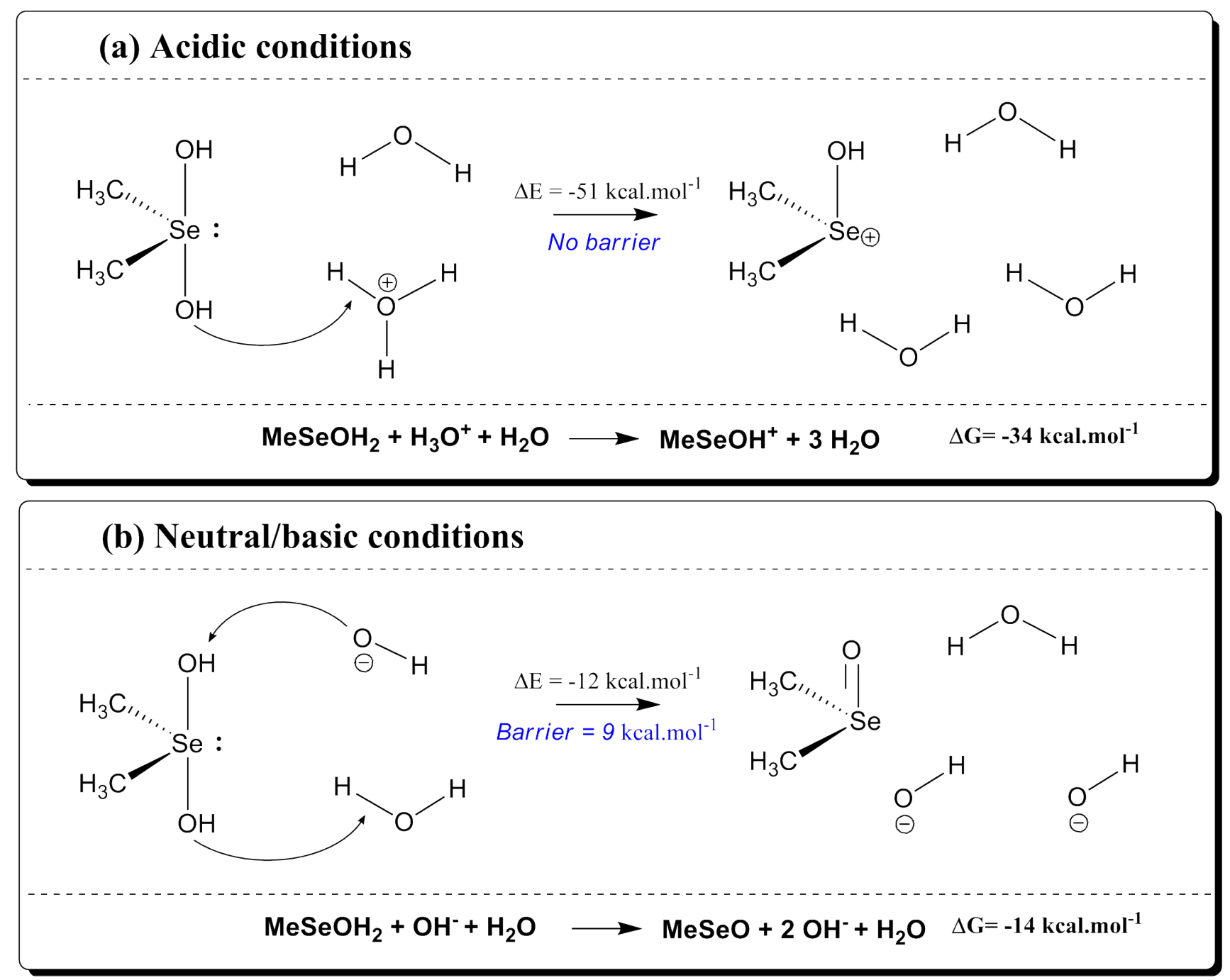

Figure 4: Mechanisms and barriers to produce the tri-coordinate species DMSeO and $\mathrm{DMseOH}^{+}$at acidic condition and (b) alkali/neutral, both starting from tetracoordinate compound C. 


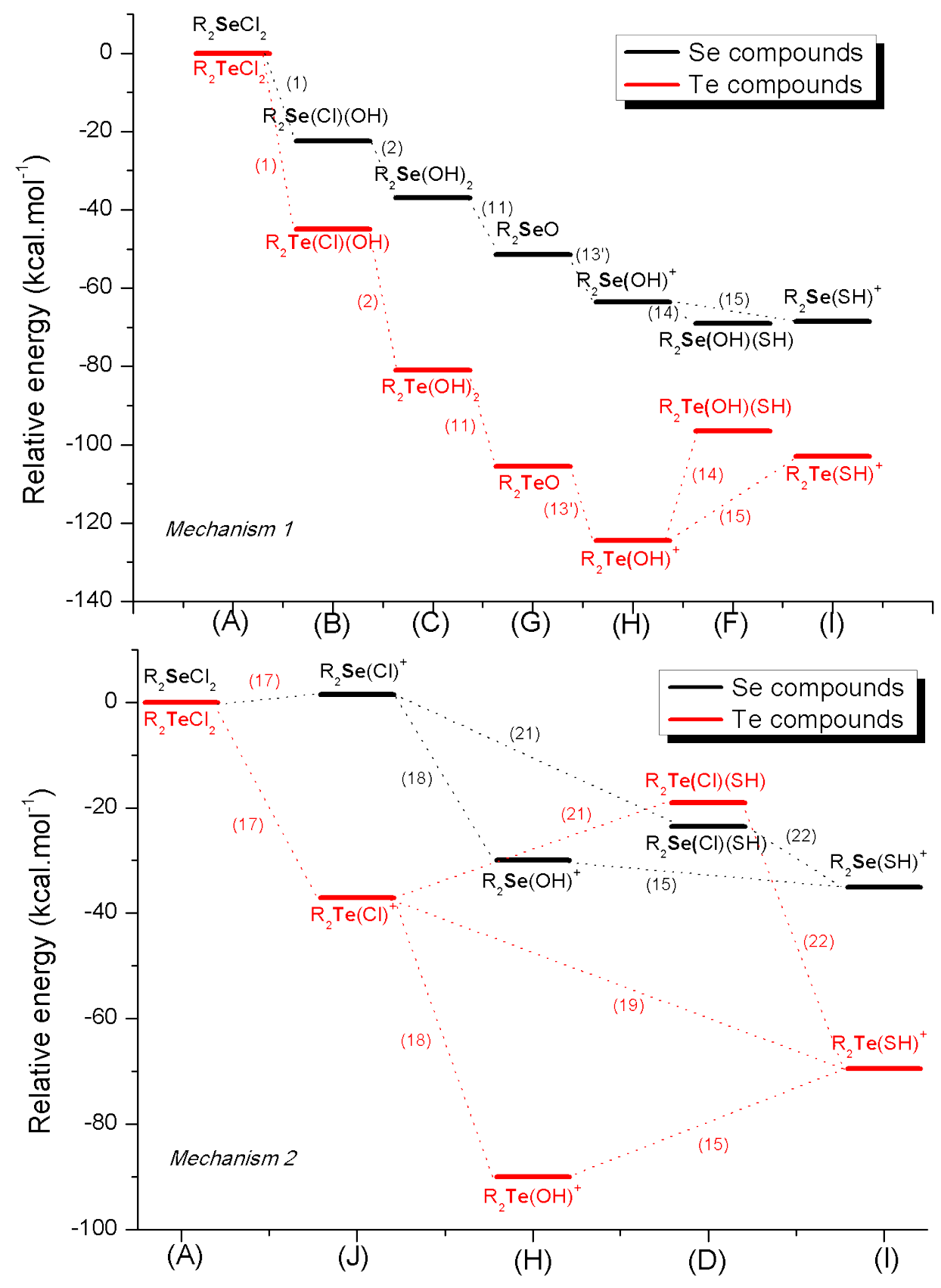

Figure 5: Mechanisms proposed to cysteine protease inhibition by selenuranes and telluranes. Compounds A to I are shown with their relative energies compared with chalcogenuranes A. The numbers describe the reactions on tables 1 and 2. Mechanism 1 describe the route involving the chalcogenoxide $\left(\mathrm{Me}_{2} \mathrm{SeO}\right.$ and $\left.\mathrm{Me}_{2} \mathrm{TeO}\right)$ formation while mechanism 2 referes to a direct pathway involving compound $\mathrm{J} \mathrm{Me}_{2} \mathrm{SeCl}^{+}$. 
Table 1: Percentage Deviation values (D) from experimental data. ${ }^{56,57}$

\begin{tabular}{ccccc}
\hline \multirow{2}{*}{$\mathbf{D}(\%)$} & \multicolumn{3}{c}{ Aug-cc-pvtz } & 6-311-6+(d) \\
& LPNO & B2PLYP & B3LYP-D3 & B3LYP-D3* \\
\hline $\mathbf{a}$ & 1.66 & 0 & 0 & 0.413 \\
$\mathbf{b}$ & 1.20 & 0.60 & 0.60 & 0.60 \\
$\alpha$ & 1.35 & 1.09 & 1.09 & 0.90 \\
$\beta$ & 0.46 & 0.80 & 0.74 & 0.87 \\
Average & 1.17 & 0.62 & 0.61 & 0.69 \\
\hline
\end{tabular}

${ }^{1}$ Standard methodology utilized in this work . 
Table 2: Gibbs free energy values $\left(k_{c a l . m o l}{ }^{-1}\right)$ for reactions 1 to 23 in neutral/alkaline conditions. Me stands for methyl, $\mathrm{Ph}$ for phenyl as $\mathrm{R}$ group.

\begin{tabular}{|c|c|c|c|c|c|}
\hline \multirow{2}{*}{$\begin{array}{l}\text { Delta Energy } \\
\qquad(\Delta E) \\
1\end{array}$} & \multicolumn{3}{|c|}{ Reaction* } & \multirow{2}{*}{$\begin{array}{c}\mathrm{R}=\mathrm{Me} \\
-22.53\end{array}$} & \multirow{2}{*}{$\begin{array}{l}\mathrm{R}=\mathrm{Ph} \\
-25.32\end{array}$} \\
\hline & $\mathrm{R}_{2} \mathrm{Se}(\mathrm{Cl})_{2}+\mathrm{OH}^{-}$ & $\longrightarrow$ & $\mathrm{R}_{2} \mathrm{Y}(\mathrm{Cl})(\mathrm{OH})+\mathrm{Cl}-$ & & \\
\hline 2 & $\mathrm{R}_{2} \mathrm{Se}(\mathrm{Cl})(\mathrm{OH})+\mathrm{OH}^{-}$ & $\longrightarrow$ & $\mathrm{R}_{2} \mathrm{Se}(\mathrm{OH})_{2}+\mathrm{Cl}^{-}$ & -14.56 & -11.23 \\
\hline 3 & $\mathrm{R}_{2} \mathrm{Se}(\mathrm{Cl})_{2}+\mathrm{SH}^{-}$ & $\longrightarrow$ & $\mathrm{R}_{2} \mathrm{Se}(\mathrm{SH})(\mathrm{Cl})+\mathrm{Cl}^{-}$ & -23.52 & -28.53 \\
\hline 4 & $\mathrm{R}_{2} \mathrm{Se}(\mathrm{Cl})_{2}+2 \mathrm{SH}^{-}$ & $\longrightarrow$ & $\mathrm{R}_{2} \mathrm{Se}(\mathrm{SH})_{2}+2 \mathrm{Cl}^{-}$ & -37.67 & -41.58 \\
\hline 5 & $\mathrm{R}_{2} \mathrm{Se}(\mathrm{OH})_{2}+2 \mathrm{SH}^{-}$ & $\longrightarrow$ & $\mathrm{R}_{2} \mathrm{Se}(\mathrm{SH})_{2}+2 \mathrm{OH}^{-}$ & -0.57 & -5.03 \\
\hline 6 & $\mathrm{R}_{2} \mathrm{Se}(\mathrm{OH})_{2}+\mathrm{SH}^{-}$ & $\longrightarrow$ & $\mathrm{R}_{2} \mathrm{Se}(\mathrm{OH})(\mathrm{SH})+\mathrm{OH}^{-}$ & 1.76 & -2.49 \\
\hline 7 & $\mathrm{R}_{2} \mathrm{Se}(\mathrm{Cl})(\mathrm{SH})+\mathrm{SH}^{-}$ & $\longrightarrow$ & $\mathrm{R}_{2} \mathrm{Se}(\mathrm{SH})_{2}+\mathrm{Cl}^{-}$ & -14.15 & -13.05 \\
\hline 8 & $\mathrm{R}_{2} \mathrm{Se}(\mathrm{OH})(\mathrm{SH})+\mathrm{SH}^{-}$ & $\longrightarrow$ & $\mathrm{R}_{2} \mathrm{Se}(\mathrm{SH})_{2}+\mathrm{OH}^{-}$ & -2.33 & -2.53 \\
\hline 9 & $\mathrm{R}_{2} \mathrm{Se}(\mathrm{Cl})(\mathrm{SH})+\mathrm{OH}^{-}$ & $\longrightarrow$ & $\mathrm{R}_{2} \mathrm{Se}(\mathrm{OH})(\mathrm{SH})+\mathrm{Cl}^{-}$ & -11.82 & -10.51 \\
\hline 10 & $\mathrm{R}_{2} \mathrm{Se}(\mathrm{Cl})_{2}+2 \mathrm{OH}^{-}$ & $\longrightarrow$ & $\mathrm{R}_{2} \mathrm{Se}(\mathrm{OH})_{2}+2 \mathrm{Cl}^{-}$ & -37.09 & -36.55 \\
\hline 11 & $\mathrm{R}_{2} \mathrm{Se}(\mathrm{OH})_{2}$ & $\longrightarrow$ & $\mathrm{R}_{2} \mathrm{SeO}+\mathrm{H}_{2} \mathrm{O}$ & -14.40 & -20.77 \\
\hline 12 & $\mathrm{R}_{2} \mathrm{Se}(\mathrm{OH})_{2}$ & $\longrightarrow$ & $\mathrm{R}_{2} \mathrm{Se}(\mathrm{OH})^{+}+\mathrm{OH}^{-}$ & 7.06 & 7.72 \\
\hline 13 & $\mathrm{R}_{2} \mathrm{SeO}+\mathrm{H}_{2} \mathrm{O}$ & $\longrightarrow$ & $\mathrm{R}_{2} \mathrm{Se}(\mathrm{OH})^{+}+\mathrm{OH}^{-}$ & 21.46 & 28.49 \\
\hline 14 & $\mathrm{R}_{2} \mathrm{Se}(\mathrm{OH})^{+}+\mathrm{SH}^{-}$ & $\longrightarrow$ & $\mathrm{R}_{2} \mathrm{Se}(\mathrm{OH})(\mathrm{SH})$ & -5.30 & -10.21 \\
\hline 15 & $\mathrm{R}_{2} \mathrm{Se}(\mathrm{OH})^{+}+\mathrm{SH}^{-}$ & $\longrightarrow$ & $\mathrm{R}_{2} \mathrm{Se}(\mathrm{SH})^{+}+\mathrm{OH}^{-}$ & -4.81 & -5.36 \\
\hline 16 & $\mathrm{R}_{2} \mathrm{Se}(\mathrm{OH})(\mathrm{SH})$ & $\longrightarrow$ & $\mathrm{R}_{2} \mathrm{Se}(\mathrm{SH})^{+}+\mathrm{OH}^{-}$ & 0.49 & 4.85 \\
\hline 17 & $\mathrm{R}_{2} \mathrm{Se}(\mathrm{Cl})_{2}$ & $\longrightarrow$ & $\mathrm{R}_{2} \mathrm{Se}(\mathrm{Cl})^{+}+\mathrm{Cl}^{-}$ & 1.51 & 1.22 \\
\hline 18 & $\mathrm{R}_{2} \mathrm{Se}(\mathrm{Cl})^{+}+\mathrm{OH}^{-}$ & $\longrightarrow$ & $\mathrm{R}_{2} \mathrm{Se}(\mathrm{OH})^{+}+\mathrm{Cl}^{-}$ & -31.54 & -30.06 \\
\hline 19 & $\mathrm{R}_{2} \mathrm{Se}(\mathrm{Cl})^{+}+\mathrm{SH}^{-}$ & $\longrightarrow$ & $\mathrm{R}_{2} \mathrm{Se}(\mathrm{SH})^{+}+\mathrm{Cl}^{-}$ & -36.36 & -35.42 \\
\hline 20 & $\mathrm{R}_{2} \mathrm{Se}(\mathrm{Cl})^{+}+\mathrm{OH}^{-}+\mathrm{H}_{2} \mathrm{O}$ & $\longrightarrow$ & $\mathrm{R}_{2} \mathrm{Se}(\mathrm{O})+\mathrm{H}_{3} \mathrm{O}^{+}+\mathrm{Cl}^{-}$ & -19.50 & -25.05 \\
\hline 21 & $\mathrm{R}_{2} \mathrm{Se}(\mathrm{Cl})^{+}+\mathrm{SH}^{-}$ & $\longrightarrow$ & $\mathrm{R}_{2} \mathrm{Se}(\mathrm{Cl})(\mathrm{SH})$ & -25.03 & -29.75 \\
\hline 22 & $\mathrm{R}_{2} \mathrm{Se}(\mathrm{Cl})(\mathrm{SH})$ & $\longrightarrow$ & $\mathrm{R}_{2} \mathrm{Se}(\mathrm{SH})^{+}+\mathrm{Cl}^{-}$ & -11.33 & -5.67 \\
\hline 23 & $\mathrm{R}_{2} \mathrm{Se}\left(\mathrm{Cl}_{2}\right)+\mathrm{OH}^{-}+\mathrm{H}_{2} \mathrm{O}$ & $\longrightarrow$ & $\mathrm{R}_{2} \mathrm{Se}(\mathrm{O})+\mathrm{H}_{3} \mathrm{O}^{+}+2 \mathrm{Cl}^{-}$ & $-18,00$ & -23.83 \\
\hline
\end{tabular}

${ }^{1}$ In these reactions the attack occurs by a nonprotonated nucleophile $\left(\mathrm{OH}^{-}\right.$and $\left.\mathrm{SH}^{-}\right)$to model a neutral/alkaline environment. 


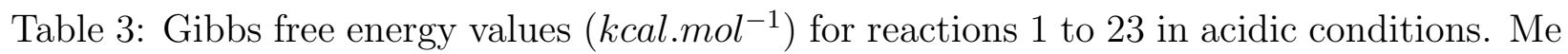
stands for methyl, $\mathrm{Ph}$ for phenyl as $\mathrm{R}$ group.

\begin{tabular}{|c|c|c|c|c|c|}
\hline \multirow{2}{*}{$\begin{array}{l}\text { Delta Energy } \\
\qquad(\Delta E) \\
1^{\prime}\end{array}$} & \multicolumn{3}{|c|}{ Reaction* } & \multirow{2}{*}{$\begin{array}{r}\mathrm{R}=\mathrm{Me} \\
10.96\end{array}$} & \multirow{2}{*}{$\begin{array}{r}\mathrm{R}=\mathrm{Ph} \\
8.17\end{array}$} \\
\hline & $\mathrm{R}_{2} \mathrm{Se}(\mathrm{Cl})_{2}+2 \mathrm{H}_{2} \mathrm{O}$ & $\longrightarrow$ & $\mathrm{R}_{2} \mathrm{Se}(\mathrm{Cl})(\mathrm{OH})+\mathrm{H}_{3} \mathrm{O}^{+}+\mathrm{Cl}^{-}$ & & \\
\hline 2 ' & $\mathrm{R}_{2} \mathrm{Se}(\mathrm{Cl})(\mathrm{OH})+2 \mathrm{H}_{2} \mathrm{O}$ & $\longrightarrow$ & $\mathrm{R}_{2} \mathrm{Se}(\mathrm{OH})_{2}+\mathrm{H}_{3} \mathrm{O}^{+}+\mathrm{Cl}^{-}$ & 18.93 & 22.27 \\
\hline 3 & $\mathrm{R}_{2} \mathrm{Se}(\mathrm{Cl})_{2}+\mathrm{H}_{2} \mathrm{~S}+\mathrm{H}_{2} \mathrm{O}$ & $\longrightarrow$ & $\mathrm{R}_{2} \mathrm{Se}(\mathrm{SH})(\mathrm{Cl})+\mathrm{H}_{3} \mathrm{O}^{+}+\mathrm{Cl}^{-}$ & -2.90 & -7.91 \\
\hline 4 & $\mathrm{R}_{2} \mathrm{Se}(\mathrm{Cl})_{2}+2 \mathrm{H}_{2} \mathrm{~S}+2 \mathrm{H}_{2} \mathrm{O}$ & $\longrightarrow$ & $\mathrm{R}_{2} \mathrm{Se}(\mathrm{SH})_{2}+2 \mathrm{H}_{3} \mathrm{O}^{+}+2 \mathrm{Cl}^{-}$ & 3.56 & -0.34 \\
\hline 5 & $\mathrm{R}_{2} \mathrm{Se}(\mathrm{OH})_{2}+2 \mathrm{H}_{2} \mathrm{~S}$ & $\longrightarrow$ & $\mathrm{R}_{2} \mathrm{Se}(\mathrm{SH})_{2}+2 \mathrm{H}_{2} \mathrm{O}$ & -26.33 & -30.78 \\
\hline 6 & $\mathrm{R}_{2} \mathrm{Se}(\mathrm{OH})_{2}+\mathrm{H}_{2} \mathrm{~S}$ & $\longrightarrow$ & $\mathrm{R}_{2} \mathrm{Se}(\mathrm{OH})(\mathrm{SH})+\mathrm{H}_{2} \mathrm{O}$ & -11.12 & -15.37 \\
\hline 7 & $\mathrm{R}_{2} \mathrm{Se}(\mathrm{Cl})(\mathrm{SH})+\mathrm{H}_{2} \mathrm{~S}+\mathrm{H}_{2} \mathrm{O}$ & $\longrightarrow$ & $\mathrm{R}_{2} \mathrm{Se}(\mathrm{SH})_{2}+\mathrm{H}_{3} \mathrm{O}^{+}+\mathrm{Cl}^{-}$ & 6.46 & 7.57 \\
\hline $8^{\prime}$ & $\mathrm{R}_{2} \mathrm{Se}(\mathrm{OH})(\mathrm{SH})+\mathrm{H}_{2} \mathrm{~S}$ & $\longrightarrow$ & $\mathrm{R}_{2} \mathrm{Se}(\mathrm{SH})_{2}+\mathrm{H}_{2} \mathrm{O}$ & -15.21 & -15.41 \\
\hline $9^{\prime}$ & $\mathrm{R}_{2} \mathrm{Se}(\mathrm{Cl})(\mathrm{SH})+2 \mathrm{H}_{2} \mathrm{O}$ & $\longrightarrow$ & $\mathrm{R}_{2} \mathrm{Se}(\mathrm{OH})(\mathrm{SH})+\mathrm{H}_{3} \mathrm{O}^{+}+\mathrm{Cl}^{-}$ & 21.67 & 22.98 \\
\hline $10^{\prime}$ & $\mathrm{R}_{2} \mathrm{Se}(\mathrm{Cl})_{2}+4 \mathrm{H}_{2} \mathrm{O}$ & $\longrightarrow$ & $\mathrm{R}_{2} \mathrm{Se}(\mathrm{OH})_{2}++2 \mathrm{H}_{3} \mathrm{O}^{+} 2 \mathrm{Cl}^{-}$ & 29.90 & 30.44 \\
\hline $13^{\prime}$ & $\mathrm{R}_{2} \mathrm{SeO}+\mathrm{H}_{3} \mathrm{O}^{+}$ & $\longrightarrow$ & $\mathrm{R}_{2} \mathrm{Se}(\mathrm{OH})^{+}+\mathrm{H}_{2} \mathrm{O}$ & -12.04 & -5.01 \\
\hline $14^{\prime}$ & $\mathrm{R}_{2} \mathrm{Se}(\mathrm{OH})^{+}+\mathrm{H}_{2} \mathrm{~S}+\mathrm{H}_{2} \mathrm{O}$ & $\longrightarrow$ & $\mathrm{R}_{2} \mathrm{Se}(\mathrm{OH})(\mathrm{SH})+\mathrm{H}_{3} \mathrm{O}^{+}$ & 15.31 & 10.41 \\
\hline 15 & $\mathrm{R}_{2} \mathrm{Se}(\mathrm{OH})^{+}+\mathrm{H}_{2} \mathrm{~S}$ & $\longrightarrow$ & $\mathrm{R}_{2} \mathrm{Se}(\mathrm{SH})^{+}+\mathrm{H}_{2} \mathrm{O}$ & -17.70 & -18.24 \\
\hline $16^{\prime}$ & $\mathrm{R}_{2} \mathrm{Se}(\mathrm{OH})(\mathrm{SH})+\mathrm{H}_{3} \mathrm{O}^{+}$ & $\longrightarrow$ & $\mathrm{R}_{2} \mathrm{Se}(\mathrm{SH})^{+}+2 \mathrm{H}_{2} \mathrm{O}$ & -33.01 & -28.65 \\
\hline $18^{\prime}$ & $\mathrm{R}_{2} \mathrm{Se}(\mathrm{Cl})^{+}+2 \mathrm{H}_{2} \mathrm{O}$ & $\longrightarrow$ & $\mathrm{R}_{2} \mathrm{Se}(\mathrm{OH})^{+}+\mathrm{H}_{3} \mathrm{O}^{+}+\mathrm{Cl}^{-}$ & 1.95 & 3.44 \\
\hline $19^{\prime}$ & $\mathrm{R}_{2} \mathrm{Se}(\mathrm{Cl})^{+}+\mathrm{H}_{2} \mathrm{~S}+\mathrm{H}_{2} \mathrm{O}$ & $\longrightarrow$ & $\mathrm{R}_{2} \mathrm{Se}(\mathrm{SH})^{+}+\mathrm{H}_{3} \mathrm{O}^{+}+\mathrm{Cl}^{-}$ & -15.74 & -14.80 \\
\hline $20^{\prime}$ & $\mathrm{R}_{2} \mathrm{Se}(\mathrm{Cl})^{+}+3 \mathrm{H}_{2} \mathrm{O}$ & $\longrightarrow$ & $\mathrm{R}_{2} \mathrm{Se}(\mathrm{O})+\mathrm{Cl}^{-}+2 \mathrm{H}_{3} \mathrm{O}^{+}$ & 13.99 & 8.44 \\
\hline $21^{\prime}$ & $\mathrm{R}_{2} \mathrm{Se}(\mathrm{Cl})^{+}+\mathrm{H}_{2} \mathrm{~S}+\mathrm{H}_{2} \mathrm{O}$ & $\longrightarrow$ & $\mathrm{R}_{2} \mathrm{Se}(\mathrm{Cl})(\mathrm{SH})+\mathrm{H}_{3} \mathrm{O}^{+}$ & -4.40 & -9.13 \\
\hline $22^{\prime}$ & $\mathrm{R}_{2} \mathrm{Se}(\mathrm{Cl})(\mathrm{SH})+2 \mathrm{H}_{2} \mathrm{O}$ & $\longrightarrow$ & $\mathrm{R}_{2} \mathrm{Se}(\mathrm{SH})^{+}+\mathrm{Cl}^{-}+\mathrm{H}_{3} \mathrm{O}^{+}+\mathrm{OH}^{-}$ & 22.16 & 27.82 \\
\hline 23 & $\mathrm{R}_{2} \mathrm{Se}\left(\mathrm{Cl}_{2}\right)+3 \mathrm{H}_{2} \mathrm{O}$ & $\longrightarrow$ & $\mathrm{R}_{2} \mathrm{Se}(\mathrm{O})+2 \mathrm{H}_{3} \mathrm{O}^{+}+2 \mathrm{Cl}^{-}$ & 15.50 & 9.66 \\
\hline
\end{tabular}




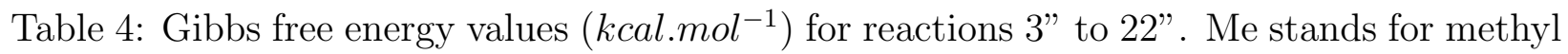
as R group and CYS for cysteine group.

\begin{tabular}{|c|c|c|c|c|}
\hline \multirow{2}{*}{$\begin{array}{l}\text { Delta Energy } \\
\qquad(\Delta E) \\
3 "\end{array}$} & \multicolumn{3}{|c|}{ Reaction* } & \multirow{2}{*}{$\begin{array}{l}\mathrm{R}=\mathrm{Me} \\
-28.18\end{array}$} \\
\hline & $\mathrm{R}_{2} \mathrm{Se}(\mathrm{Cl})_{2}+\mathrm{CYS}^{-}$ & $\longrightarrow$ & $\mathrm{R}_{2} \mathrm{Se}(\mathrm{CYS})(\mathrm{Cl})+\mathrm{Cl}^{-}$ & \\
\hline $4 "$ & $\mathrm{R}_{2} \mathrm{Se}(\mathrm{Cl})_{2}+2 \mathrm{CYS}^{-}$ & $\longrightarrow$ & $\mathrm{R}_{2} \mathrm{Se}(\mathrm{CYS})_{2}+2 \mathrm{Cl}^{-}$ & -39.76 \\
\hline $5 "$ & $\mathrm{R}_{2} \mathrm{Se}(\mathrm{OH})_{2}+2 \mathrm{CYS}^{-}$ & $\longrightarrow$ & $\mathrm{R}_{2} \mathrm{Se}(\mathrm{CYS})_{2}+2 \mathrm{OH}^{-}$ & -2.66 \\
\hline $6 "$ & $\mathrm{R}_{2} \mathrm{Se}(\mathrm{OH})_{2}+\mathrm{CYS}^{-}$ & $\longrightarrow$ & $\mathrm{R}_{2} \mathrm{Se}(\mathrm{OH})(\mathrm{CYS})+\mathrm{OH}^{-}$ & -1.50 \\
\hline $7 "$ & $\mathrm{R}_{2} \mathrm{Se}(\mathrm{Cl})(\mathrm{CYS})+\mathrm{CYS}^{-}$ & $\longrightarrow$ & $\mathrm{R}_{2} \mathrm{Se}(\mathrm{CYS})_{2}+\mathrm{Cl}^{-}$ & -11.58 \\
\hline $8 "$ & $\mathrm{R}_{2} \mathrm{Se}(\mathrm{OH})(\mathrm{CYS})+\mathrm{CYS}^{-}$ & $\longrightarrow$ & $\mathrm{R}_{2} \mathrm{Se}(\mathrm{CYS})_{2}+\mathrm{OH}^{-}$ & -1.16 \\
\hline $9 "$ & $\mathrm{R}_{2} \mathrm{Se}(\mathrm{Cl})(\mathrm{CYS})+\mathrm{OH}^{-}$ & $\longrightarrow$ & $\mathrm{R}_{2} \mathrm{Se}(\mathrm{OH})(\mathrm{CYS})+\mathrm{Cl}^{-}$ & -10.42 \\
\hline $14 "$ & $\mathrm{R}_{2} \mathrm{Se}(\mathrm{OH})^{+}+\mathrm{CYS}^{-}$ & $\longrightarrow$ & $\mathrm{R}_{2} \mathrm{Se}(\mathrm{OH})(\mathrm{CYS})$ & -8.56 \\
\hline $15 "$ & $\mathrm{R}_{2} \mathrm{Se}(\mathrm{OH})^{+}+\mathrm{CYS}^{-}$ & $\longrightarrow$ & $\mathrm{R}_{2} \mathrm{Se}(\mathrm{CYS})^{+}+\mathrm{OH}^{-}$ & -9.00 \\
\hline $16 "$ & $\mathrm{R}_{2} \mathrm{Se}(\mathrm{OH})(\mathrm{CYS})$ & $\longrightarrow$ & $\mathrm{R}_{2} \mathrm{Se}(\mathrm{CYS})^{+}+\mathrm{OH}^{-}$ & -0.43 \\
\hline $19 "$ & $\mathrm{R}_{2} \mathrm{Se}(\mathrm{Cl})^{+}+\mathrm{CYS}^{-}$ & $\longrightarrow$ & $\mathrm{R}_{2} \mathrm{Se}(\mathrm{CYS})^{+}+\mathrm{Cl}^{-}$ & -40.54 \\
\hline $21 "$ & $\mathrm{R}_{2} \mathrm{Se}(\mathrm{Cl})^{+}+\mathrm{CYS}^{-}$ & $\longrightarrow$ & $\mathrm{R}_{2} \mathrm{Se}(\mathrm{Cl})(\mathrm{CYS})$ & -29.69 \\
\hline $22 "$ & $\mathrm{R}_{2} \mathrm{Se}(\mathrm{Cl})(\mathrm{CYS})$ & $\longrightarrow$ & $\mathrm{R}_{2} \mathrm{Se}(\mathrm{CYS})^{+}+\mathrm{Cl}^{-}$ & -10.85 \\
\hline
\end{tabular}

${ }^{1}$ In these reactions the attack occurs by a nonprotonated nucleophile $\left(\mathrm{OH}^{-}\right.$and $\left.\mathrm{CYS}^{-}\right)$to model a cysteine in the ezmimatic environment. 